\title{
Nauplius
}

The Journal OF The

Brazilian Crustacean Society

e-ISSN 2358-2936

www.scielo.br/nau www.crustacea.org.br

\section{Color variation of the freshwater crab Dilocarcinus pagei Stimpson, 1861 captured in the Amazon region at Itacoatiara, Amazonas, Brazil}

\author{
Nelcilene de Almeida Pontes (D) orcid.org/0000-0002-9042-7934 \\ Bruno Sampaio Sant’Anna (D) orcid.org/0000-0001-9689-4894 \\ Gustavo Yomar Hattori (D) orcid.org/0000-0003-0352-9308 \\ Universidade Federal do Amazonas (UFAM), Instituto de Ciências Exatas \\ e Tecnologia (ICET). 69103-128, Itacoatiara, AM, Brasil. \\ NAP E-mail: nelcilene.almeida@gmail.com \\ BSS E-mail: brunusant@hotmail.com \\ GYH E-mail: hattori@ufam.edu.br
}

ZOOBANK: http://zoobank.org/urn:lsid:zoobank.org:pub:6FCC157D-944A-40A4AD64-6BA8069C8ED4

\section{AbSTRACt}

The relationship between color and size supports the hypothesis that color is an important signal for some crab species during mating rituals or agonistic interactions. Thus, the objective of this study was to describe the color variation of $D$. pagei and its relationship with sex and sexual maturity. The crabs were placed on a surface for photographic recording of the body parts: cephalothorax, chelipeds, abdomen and pereiopods using a digital camera installed on a photographic table. Images were converted to the spectrum of red, green, blue and also of them combined (RGB). The values of each spectrum revealed that the color variation of the cephalothorax and chelipeds were different between adults and juveniles. The abdomen and pereiopods showed color variation in both sexes and at developmental stages. The pattern of color variation observed in juveniles ranged from light to dark brown and adults are from orange to intense red. The change in color of the cephalothorax and chelipeds could be used as a character to determine the onset of sexual maturity. The high color variation of the abdomen and pereiopods in both sexes and at developmental stages, though, indicates individual variation which probably is associated with other factors, such as molt stage or even the quality of food available.

CORRESPONDING AUTHOR Gustavo Yomar Hattori hattori@ufam.edu.br

SUBMITTED 1 September 2019 ACCEPTED 16 March 2020 PUBLISHED 13 July 2020

DOI $10.1590 / 2358-2936 e 2020026$

\section{(cc) BY}

All content of the journal, except where identified, is licensed under a Creative Commons attribution-type BY.

Nauplius, 28: e2020026

\section{KEYWORDS}

Brachyura, Crustacea, dimorphism, Trichodactylidae 


\section{INTRODUCTION}

Among the Neotropical freshwater crabs are the families Pseudothelphusidae Ortmann, 1893 and Trichodactylidae H. Milne Edwards, 1853, which have species unique to the Amazon region (Magalhães et al., 2016). The Trichodactylidae is composed of 50 semiterrestrial species distributed in Central and South America, from southern Mexico to Argentina (Yeo et al., 2008; Magalhães et al., 2016). Dilocarcinus pagei Stimpson, 1861, is one of the representative species of this family in the Amazon region, and typically occurs in the floodplain areas, near to rivers and lakes, where it is often found associated with aquatic vegetation in backwaters and marshy areas (Magalhães, 2016).

According to Taddei and Herrera (2010), D. pagei females can reproduce during the first year of life and can reach morphological sexual maturity at smaller sizes than males (Herrera et al., 2013). In Arenaeus cribrarius (Lamarck, 1818) and Charybdis hellerii (A. Milne-Edwards, 1867), sexual maturity is associated with changes in female abdomen color (Pinheiro and Taddei, 2000; Watanabe et al., 2015). Furthermore, in $C$. hellerii the color pattern changes with animal size, with smaller and immature individuals being darker than larger and mature individuals (Watanabe et al., 2015).

The ability to alter body pigmentation by chromatophores or pigment cells is common in the animal kingdom, especially in ectothermic animals, including crustaceans (Thurman, 1988). According to this author, coloration in decapod crustaceans is determined by the number, type and distribution of chromatophores. Such color changes can have numerous functions, including inter- or intraspecific communication (Detto et al., 2006; Cummings et al., 2008) and/or camouflage strategies (Hemmi et al., 2006). The main chromatophores present in crustaceans are homochromes, erythrophores and xanthophores that have carotenoid and peridine pigments in different proportions (Ghidalia, 1985). Crustaceans are rich in carotenoids, most of them existing as astaxanthin (Shahidi and Synowiecki, 1991; Matsuno, 2001), and in particular, the intensity of the reddish coloration of shrimp and other crustaceans is controlled by the concentration of this carotenoid (Maoka, 2011).
According to Detto et al. (2004), the existence of a relationship between color and individual crab size supports the hypothesis that color is an important signal for the crab Heloecius cordiformis (H. Milne Edwards, 1837) during mating rituals or aggressive interactions. In Austruca mjoebergi (Rathbun, 1924), females use male cheliped color, regardless of their specific waving display, to identify them as members of the same species (Detto, 2007). Males of Tubuca capricornis (Crane, 1975) recognize neighboring females based on the distinct color patterns of their cephalothorax (Detto et al., 2006).

Dilocarcinus pagei is one of the most studied freshwater crab species in Brazil, and there is already published information on population dynamics (Davanso et al., 2013), behavior (Affonso and Signorelli, 2011; Sant'Anna et al., 2014; Senkman et al., 2015), experimental culture (Sant'Anna et al., 2015), and sexual maturity and dimorphism, (Davanso et al., 2016), but there is no information on the coloration patterns of this species. Thus, this study evaluated the color variation in D. pagei and its relationship with the sex and sexual maturity of these crabs.

\section{Material and Methods}

\section{Collection of samples}

The specimens were collected in the municipality of Itacoatiara (AM) in a floodplain area called Poranga (0307'11.4” S; 58²7’1.0” W), between August 2016 and April 2017 (Fig. 1). The crabs were collected on the sediment surface and among the adjacent macrophytic vegetation. The crustaceans were packed in plastic boxes with water and aeration and transported to the laboratory.

In the laboratory, the animals were identified according to the morphological characteristics described by Magalhães (2003). The crabs were sexed by the inspection of abdomen morphology and all animals was measured with a caliper $(0.05 \mathrm{~mm})$. The size of the carapace width was used to separate the onset of morphological sexual maturity, which was previously determined to be $28.7 \mathrm{~mm}$ for males and $24.2 \mathrm{~mm}$ for females (Davanso et al., 2016). 


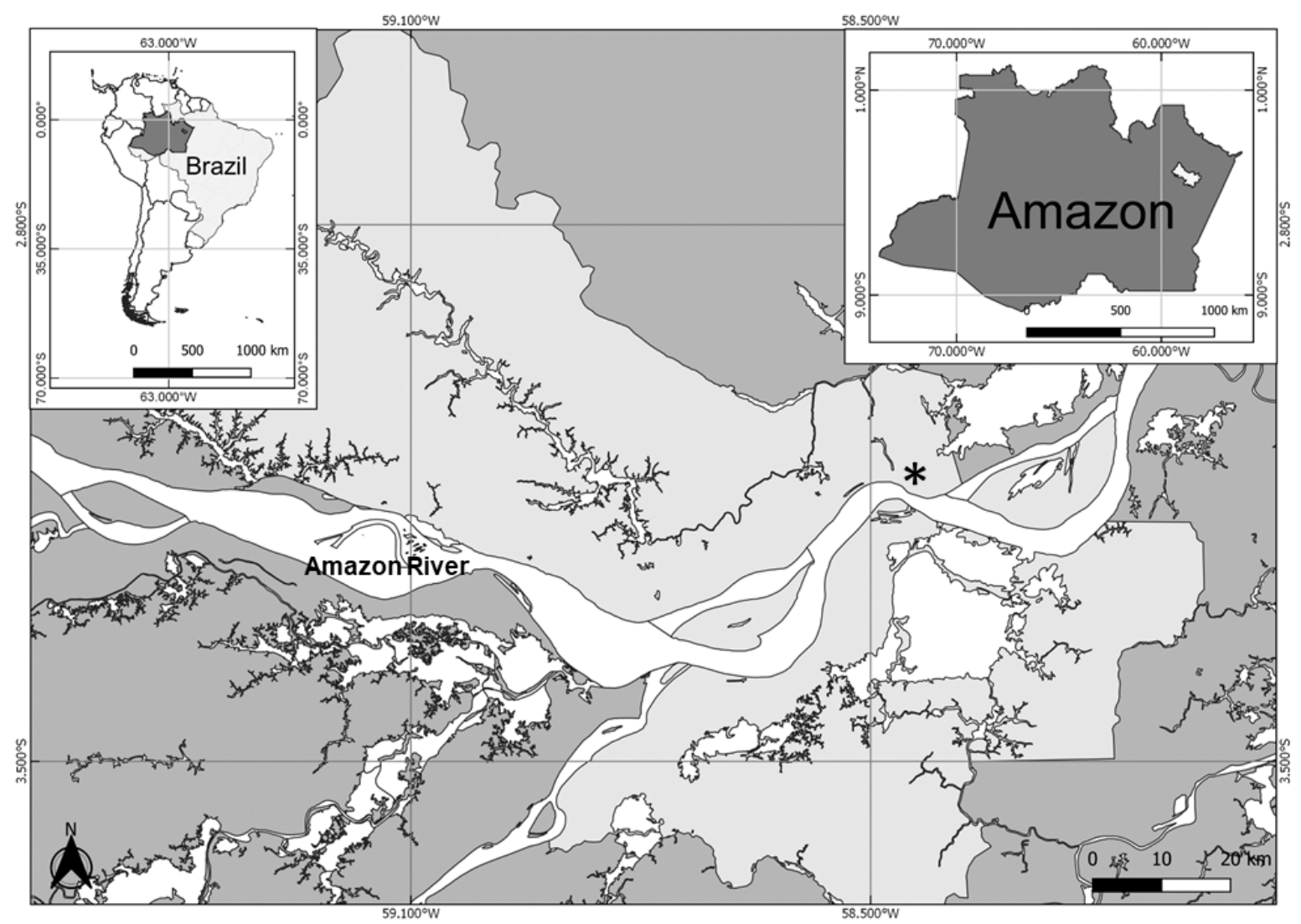

Figure 1. Map of the floodplain area known as Poranga $\left({ }^{*}\right)$ in the municipality of Itacoatiara, Amazonas, Brazil.

\section{Image and color analysis}

The crabs were photographed using a NIKON Coolpix L810 digital camera with 4.0-104 mm lens, attached to a specific table with a fixed height of $20 \mathrm{~cm}$ from the base, and with lighting from two $20 \mathrm{~W}$ fluorescent lamps, behind a refractory surface to avoid reflections.

The camera was adjusted to capture standard white balance images without additional color filtering and with a shutter speed of $1 / 1500 \mathrm{~s}$ to standardize the image brightness error. Images were converted to red $(\mathrm{R})$, green $(\mathrm{G})$, blue (B) and combined RGB values (interaction of the values of the three colors).

The recorded values of the images were collected from a histogram provided by free software GIMP (GNU Image Manipulation Program, EUA) obtained from the selected area of each morphological structure (cephalothorax surface, external surface of chelipeds, abdomen and pereiopods). This software has the same accuracy as other software described by Watanabe $e t$ al. (2015) who investigated the coloring pattern of the crab C. hellerii.
Digital images were individually analyzed using the color spectra of red, green and blue values ranging from 0 to 255. The RGB system combines the color spectra (Red, Green and Blue) in values of intensity with ranges from 0 to 255 ( 8 bits) for each color. The combination of values represents the individual colors with high values representing light colors and low values corresponding to dark colors (Casariego et al., 2011; Nasir and Faulkes, 2011).

\section{Statistical analysis}

The data for each color spectrum (R, G, B and RGB) from the images of the morphological structures were submitted to the Kolmogorov-Smirnov normality test. As the values did not show a normal distribution $(\mathrm{P}<0.05)$, a transformation by square root was applied to increase the normality of the distribution.

The influence of sex and developmental stage on color variation of $D$. pagei was verified by the mean value of each color spectrum (R, G, B and RGB). Each morphological structure (cephalothorax, abdomen, external face of chelipeds and pereiopods) were 
submitted to analysis of variance (ANOVA two-way) considering sex (male and female) and developmental stage based on the size of the onset sexual maturity (juveniles and adults).

\section{ResUlts}

A total of 186 crabs were collected (100 males and 86 females) and the mean size registered for each sex and developmental stage was similar (Tab. 1). The visible color variation of Dilocarcinus pagei shows two morphotypes at each developmental stage, with juveniles ranging from light to dark brown, and adults separated into the groups light orange to red (Fig. 2).

The color variation pattern observed in the developmental stage indicated a significant difference between juveniles and adults. The cephalothorax and chelipeds show differences between the adults and juveniles, but with no differences between sexes (Tab.2). In the same table, the color of the abdomen and pereiopods was different between the sexes and in sexual maturity.

The means of the combined RGB spectra from the cephalothorax and chelipeds were higher in adults than in juveniles, indicating a darker color in adults and a lighter color in juveniles (Tab. 3). This same pattern of color spectrum was observed in the green and blue spectra. The red spectrum, though, was similar between the developmental stages.

The abdomen shows different colors in adult males with lower values of combined RGB spectra when compared to juvenile males and all females (adults and juveniles). The red color of the abdomen in adult males was confirmed by the lower values of the green and blue spectra (Tab. 4).

The values of the combined RGB spectra from the pereiopods demonstrated a different color between adults and juveniles, with adults being darker than juveniles. The same pattern was seen for the individual red, green and blue spectra (Tab. 4).

Table 1. Carapace width ( $\mathrm{mm})$ of Dilocarcinus pagei for males and females used in the experiment. $\mathrm{N}=\mathrm{Number}$ of individuals; $\mathrm{M}=$ male; $\mathrm{F}=$ female; $\mathrm{X}=$ mean; $\mathrm{SD}=$ standard deviation.

\begin{tabular}{|c|c|c|c|c|c|c|c|c|}
\hline \multirow{2}{*}{ Size } & \multicolumn{2}{|c|}{$\mathbf{N}$} & \multicolumn{2}{|c|}{ Minimum } & \multicolumn{2}{|c|}{ Maximum } & \multicolumn{2}{|c|}{$\mathbf{X} \pm \mathbf{S D}$} \\
\hline & $\mathrm{M}$ & F & M & $\mathrm{F}$ & M & $\mathrm{F}$ & M & $\mathrm{F}$ \\
\hline Juvenile & 40 & 40 & 11.34 & 11.00 & 28.47 & 23.40 & $16.39 \pm 3.49$ & $17.08 \pm 3.32$ \\
\hline Adult & 60 & 46 & 34.82 & 32.07 & 49.56 & 50.78 & $42.74 \pm 3.89$ & $40.30 \pm 4.06$ \\
\hline
\end{tabular}

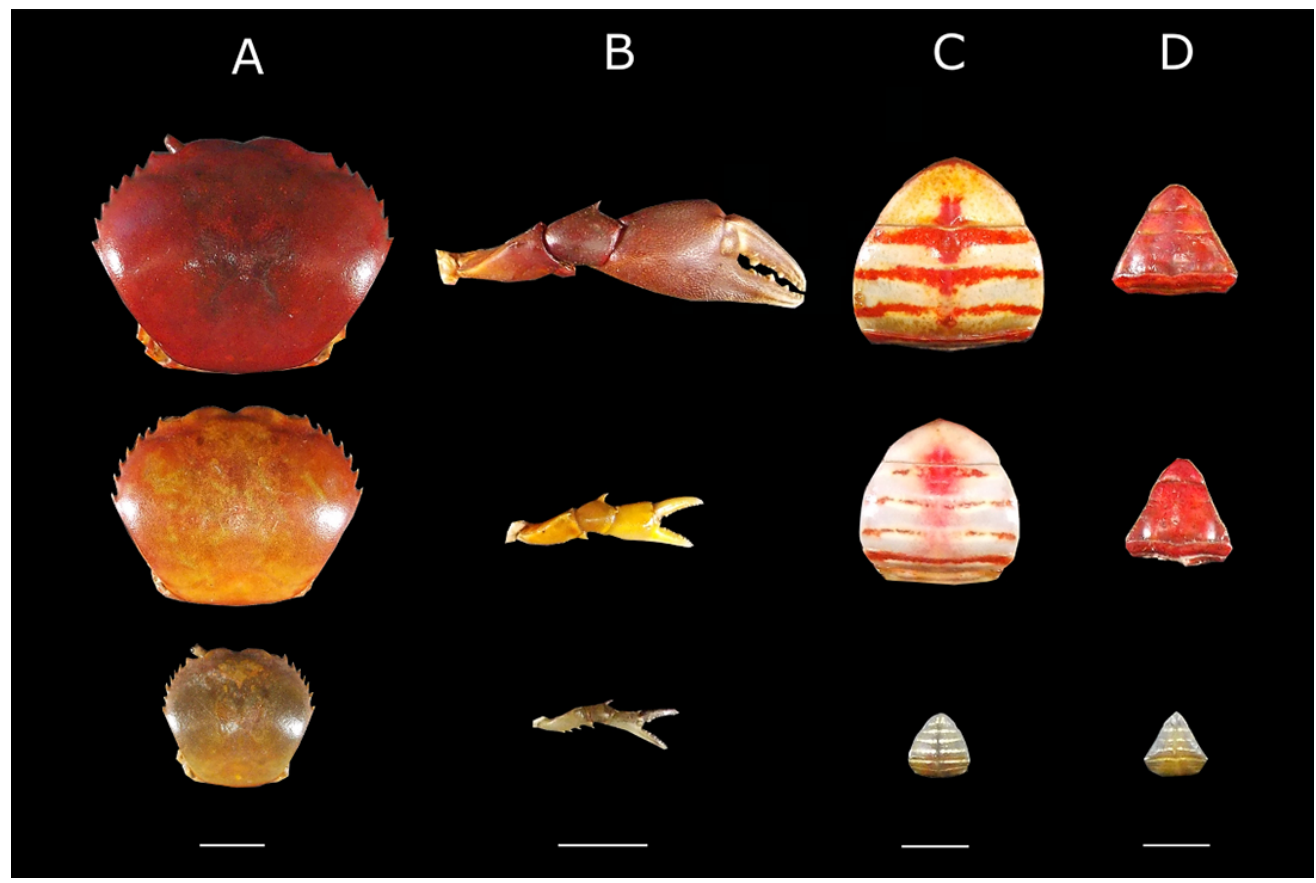

Figure 2. Color variation of Dilocarcinus pagei separated by size and morphological structure. ( $\mathbf{A}=$ cephalothorax; $\mathbf{B}=$ chelipeds; $\mathbf{C}=$ female abdomen; $\mathbf{D}=$ male abdomen; scale bar $=1 \mathrm{~cm}$ ). 
Table 2. Comparison of Dilocarcinus pagei by factorial analysis of variance (ANOVA two-way) of cephalothorax, abdomen, cheliped and pereiopod by color spectrum (red, blue, green and RGB). DF = Degrees of freedom; MS = mean square; F = test value F; $P=$ significance.

\begin{tabular}{|c|c|c|c|c|c|c|c|c|c|}
\hline & \multirow[b]{2}{*}{ Variables } & \multicolumn{4}{|c|}{ Cephalothorax } & \multicolumn{4}{|c|}{ Abdomen } \\
\hline & & $\mathrm{DF}$ & MS & $\mathrm{F}$ & $P$ & $\mathrm{DF}$ & MS & $\mathrm{F}$ & $P$ \\
\hline \multirow{3}{*}{ 邑 } & Sex & 1 & 0.72 & 1.11 & 0.2939 & 1 & 27.04 & 6.991 & 0.0089 \\
\hline & Maturity & 1 & 11.15 & 17.24 & 0.0001 & 1 & 28.31 & 7.319 & 0.0075 \\
\hline & Sex vs. Maturity & 1 & 0.71 & 1.10 & 0.2953 & 1 & 118.40 & 30.612 & 0.0000 \\
\hline \multirow{3}{*}{ 至 } & Sex & 1 & 0.01 & 0.01 & 0.9156 & 1 & 3.65 & 7.280 & 0.0076 \\
\hline & Maturity & 1 & 9.69 & 9.93 & 0.0019 & 1 & 66.28 & 132.070 & 0.0000 \\
\hline & Sex vs. Maturity & 1 & 0.26 & 0.27 & 0.6046 & 1 & 6.29 & 12.530 & 0.0005 \\
\hline \multirow{3}{*}{$\begin{array}{l}\text { Z } \\
\text { 賃 } \\
\text { 出 }\end{array}$} & Sex & 1 & 0.00 & 0.00 & 0.9515 & 1 & 183.78 & 237.940 & 0.0000 \\
\hline & Maturity & 1 & 193.04 & 203.88 & 0.0000 & 1 & 105.06 & 136.020 & 0.0000 \\
\hline & Sex vs. Maturity & 1 & 6.15 & 6.49 & 0.0117 & 1 & 183.40 & 237.450 & 0.0000 \\
\hline \multirow{4}{*}{$\begin{array}{l}\text { 茨 } \\
\stackrel{9}{口}\end{array}$} & Sex & 1 & 22.81 & 23.36 & 0.0000 & 1 & 68.63 & 54.12 & 0.0000 \\
\hline & Maturity & 1 & 4.83 & 4.95 & 0.0273 & 1 & 120.11 & 94.73 & 0.0000 \\
\hline & Sex vs. Maturity & 1 & 0.05 & 0.05 & 0.8244 & 1 & 122.25 & 96.41 & 0.0000 \\
\hline & & \multicolumn{4}{|c|}{ Cheliped } & \multicolumn{4}{|c|}{ Pereiopod } \\
\hline \multirow{3}{*}{ 氖 } & Sex & 1 & 3.91 & 7.94 & 0.0054 & 1 & 0.00 & 0.00 & 0.9471 \\
\hline & Maturity & 1 & 20.56 & 41.79 & 0.0000 & 1 & 34.94 & 105.72 & 0.0000 \\
\hline & Sex vs. Maturity & 1 & 0.97 & 1.97 & 0.1617 & 1 & 5.44 & 16.47 & 0.0000 \\
\hline \multirow{3}{*}{ 至 } & Sex & 1 & 0.96 & 1.88 & 0.1721 & 1 & 0.34 & 1.03 & 0.3116 \\
\hline & Maturity & 1 & 28.66 & 56.28 & 0.0000 & 1 & 47.31 & 144.42 & 0.0000 \\
\hline & Sex vs. Maturity & 1 & 1.06 & 2.08 & 0.1507 & 1 & 5.38 & 16.41 & 0.0001 \\
\hline \multirow{3}{*}{$\begin{array}{l}\text { Z } \\
\text { 丽 } \\
\text { 出 }\end{array}$} & Sex & 1 & 2.13 & 3.14 & 0.0780 & 1 & 1.64 & 3.03 & 0.0837 \\
\hline & Maturity & 1 & 94.30 & 139.20 & 0.0000 & 1 & 217.96 & 401.93 & 0.0000 \\
\hline & Sex vs. Maturity & 1 & 1.65 & 2.43 & 0.1204 & 1 & 10.72 & 19.76 & 0.0000 \\
\hline \multirow{3}{*}{ 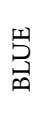 } & Sex & 1 & 13.34 & 19.78 & 0.0000 & 1 & 7.31 & 9.21 & 0.0028 \\
\hline & Maturity & 1 & 172.60 & 255.94 & 0.0000 & 1 & 202.06 & 254.58 & 0.0000 \\
\hline & Sex vs. Maturity & 1 & 0.00 & 0.00 & 0.9831 & 1 & 1.16 & 1.46 & 0.2286 \\
\hline
\end{tabular}

*values in bold are significant $\mathrm{P}<0.05$.

Table 3. Spectrum color values of Dilocarcinus pagei for adults and juvenile by morphological structure. Min. = minimum; Max. = maximum; $\mathrm{X}=$ mean; $\mathrm{SD}=$ standard deviation.

\begin{tabular}{|c|c|c|c|c|c|c|}
\hline \multicolumn{7}{|c|}{ Cephalothorax } \\
\hline & \multicolumn{3}{|c|}{ Adult } & \multicolumn{3}{|c|}{ Juvenile } \\
\hline & Min & $\operatorname{Max}$ & $\mathrm{X} \pm \mathrm{SD}$ & Min & Max & $\mathrm{X} \pm \mathrm{SD}$ \\
\hline RGB & 70.1 & 142.2 & $95.2 \pm 10.8$ & 48.0 & 180.0 & $106.3 \pm 22.7$ \\
\hline RED & 101.1 & 205.7 & $156.4 \pm 19.0$ & 48.0 & 207.8 & $146.1 \pm 28.5$ \\
\hline GREEN & 48.1 & 127.4 & $71.7 \pm 9.13 .9$ & 48.0 & 195.4 & $113.1 \pm 26.1$ \\
\hline BLUE & 33.6 & 83.0 & $56.3 \pm 10.9$ & 32.7 & 154.0 & $61.9 \pm 23.8$ \\
\hline \multicolumn{7}{|c|}{ Cheliped } \\
\hline & \multicolumn{3}{|c|}{ Adult } & \multicolumn{3}{|c|}{ Juvenile } \\
\hline & Min & Max & $\mathrm{X} \pm \mathrm{SD}$ & Min & Max & $\mathrm{X} \pm \mathrm{SD}$ \\
\hline RGB & 105.6 & 167.0 & $131.2 \pm 11.6$ & 112.5 & 208.6 & $148.3 \pm 22.0$ \\
\hline RED & 145.8 & 228.0 & $196.2 \pm 16.8$ & 139.7 & 233.0 & $175.3 \pm 22.4$ \\
\hline GREEN & 91.5 & 176.3 & $119.3 \pm 16.2$ & 118.2 & 217.1 & $154.1 \pm 22.4$ \\
\hline BLUE & 49.6 & 113.8 & $77.7 \pm 12.0$ & 78.5 & 184.4 & $115.5 \pm 23.0$ \\
\hline
\end{tabular}


Table 4. Spectrum color values of Dilocarcinus pagei for males and females by morphological structure and developmental stage. Min. = minimum; Max. $=$ maximum; $\mathrm{X}=$ mean; $\mathrm{SD}=$ standard deviation.

\begin{tabular}{|c|c|c|c|c|c|c|c|c|c|c|c|c|}
\hline \multicolumn{13}{|c|}{ Abdomen } \\
\hline \multicolumn{7}{|c|}{ Adult } & \multicolumn{6}{|c|}{ Juvenile } \\
\hline & \multicolumn{3}{|c|}{ M } & \multicolumn{3}{|c|}{$\mathrm{F}$} & \multicolumn{3}{|c|}{$\mathrm{M}$} & \multicolumn{3}{|c|}{$\mathrm{F}$} \\
\hline & Min & $\operatorname{Max}$ & $\mathrm{X} \pm \mathrm{SD}$ & Min & $\operatorname{Max}$ & $\mathrm{X} \pm \mathrm{SD}$ & Min & $\operatorname{Max}$ & $\mathrm{X} \pm \mathrm{SD}$ & Min & $\operatorname{Max}$ & $\mathrm{X} \pm \mathrm{SD}$ \\
\hline RGB & 100.2 & 169.9 & $128 \pm 13.1$ & 143.3 & 214.9 & $187.8 \pm 18.1$ & 137.1 & 228.7 & $171.5 \pm 26.9$ & 138.6 & 215.6 & $165.9 \pm 18.9$ \\
\hline RED & 172.7 & 232.7 & $212.5 \pm 11.9$ & 136.2 & 248.2 & $232.5 \pm 21.8$ & 152.7 & 238.1 & $189.5 \pm 25.3$ & 157.8 & 224.5 & $186.7 \pm 19.3$ \\
\hline GREEN & 67.9 & 149.9 & $93.5 \pm 16.4$ & 128.2 & 223.1 & $187.4 \pm 22.4$ & 103.7 & 231.9 & $174.7 \pm 29.1$ & 142.5 & 217.1 & $174.1 \pm 19.3$ \\
\hline BLUE & 55.1 & 127.2 & $79.1 \pm 15.2$ & 75.2 & 183.5 & $139.2 \pm 29.2$ & 87 & 215.9 & $148.9 \pm 33.8$ & 99.9 & 212.2 & $138.4 \pm 25.7$ \\
\hline \multicolumn{13}{|c|}{ Pereiopod } \\
\hline & \multicolumn{6}{|c|}{ Adult } & \multicolumn{6}{|c|}{ Juvenile } \\
\hline & \multicolumn{3}{|c|}{$\mathrm{M}$} & \multicolumn{3}{|c|}{$\mathrm{F}$} & \multicolumn{3}{|c|}{$M$} & \multicolumn{3}{|c|}{$\mathrm{F}$} \\
\hline & Min & $\operatorname{Max}$ & $\mathrm{X} \pm \mathrm{SD}$ & Min & Max & $\mathrm{X} \pm \mathrm{SD}$ & Min & Max & $\mathrm{X} \pm \mathrm{SD}$ & Min & $\operatorname{Max}$ & $\mathrm{X} \pm \mathrm{SD}$ \\
\hline RGB & 100.3 & 135.5 & $117.7 \pm 8$ & 103.3 & 169.3 & $125.4 \pm 12.4$ & 105.6 & 193 & $146.3 \pm 20.3$ & 118.9 & 177.3 & $137.6 \pm 13.3$ \\
\hline RED & 161 & 207.8 & $187.9 \pm 10.5$ & 162.8 & 223.5 & $200 \pm 14.2$ & 126.5 & 216.6 & $170.3 \pm 21.7$ & 142 & 205.8 & $163.3 \pm 14.6$ \\
\hline GREEN & 67.4 & 112.9 & $92.6 \pm 10.4$ & 76.3 & 179.4 & $106.6 \pm 19.8$ & 101.2 & 197 & $151.7 \pm 21.8$ & 125.1 & 186.6 & $144.1 \pm 13.8$ \\
\hline BLUE & 50.8 & 100.3 & $72.8 \pm 10.9$ & 34.1 & 122.9 & $69.5 \pm 18.8$ & 75.4 & 166.4 & $117.1 \pm 21.2$ & 69.6 & 144.7 & $105.1 \pm 16.8$ \\
\hline
\end{tabular}

\section{Discussion}

The external color of $D$. pagei varies from light brown to red, confirmed by the different values in the green and blue color spectra. This color variation is associated with growth of morphological structures. According to Rao (2001), the movement of pigments promotes a dispersion or concentration at the epithelial chromatophores causing the color changes in crustaceans.

The color variation between adults and juveniles of $D$. page $i$ is related to pigment change after reaching sexual maturity, with adults showing dark colors and juveniles are lighter in color. In addition, color intensity may also vary during molting with adjustments in chromatophores, as seen by Casariego et al. (2011), with color associated with the interval of molting period.

In this study, adults of $D$. pagei showed post-moult colors of orange, brown and red. In Carcinus maenas (Linnaeus, 1758) color change was found in females during periods of high molting frequency after mating; becoming red in the intermolt periods and green after molting (Lee and Vespoli, 2015). The color of the cephalothorax in Cardisoma guanhumi Latreille 1825 could be associated with developmental stage because there is a relationship with molting frequency and the size at onset of sexual maturity (Silva et al., 2014). Adults of D. pagei have cephalothorax shades of red and orange, suggesting that these differences may influence the behavior of individuals as shown by Casariego et al. (2011) and Lee and Vespoli (2015) who all reported the importance of cephalothorax color variation in crab social interactions.

Males and females of $D$. pagei have different color variations on their abdomen, with females showing a red background with white spots, while males are fully intense red. This information could be important to help identify the onset of sexual maturity, since the color of the juvenile abdomen is completely brown in both sexes.

The mangrove crab Austruca perplexa (H. Milne Edwards, 1852) has the abdomen color as an important indicator of sexual maturity or sex, because it relies more on visual than chemical cues (Takeda, 2006). According to the same author, the intense color of adult females is a character used to distinguish mature from immature females, as well as assisting in visual identification of other sympatric crab species. The presence of white spots on the abdomen of $D$. pagei females may be caused by natural wear during locomotion. The abdomen experiences positive allometric growth because it has the function of incubation chamber during reproduction (Davanso et al., 2016). This positive allometric growth may alter the concentration of chromophores in the abdomen as observed in $C$. hellerii and $A$. cribrarius 
by Watanabe et al. (2015) and Pinheiro and Taddei (2000), respectively.

The color variation of the chelipeds and pereiopods of $D$. pagei shows the same pattern as the cephalothorax. Juveniles present a brown coloration without difference between sexes, while adults present colors ranging from red to orange. This pattern is associated with the diverse functions of chelipeds during development, such as in females where they may promote protection of eggs and juveniles stored on the abdomen against predators (Daniels, 2001), and in males where they are used in mating behavioral displays (Herrera et al., 2013).

The color variation during ontogeny observed in D. pagei may be associated with the growth of these morphological structures, as shown in studies with the crab H. cordiformis, whose color is related to growth and may be promoted by foraging habits or the acquisition of sexual maturity (Detto et al., 2004).

The positive and negative relationships of color intensity recorded in $D$. pagei may further indicate the existence of a hierarchy in this species and could be an important character during territorial disputes or choice of partners; as noted in the blue crab Callinectes sapidus Rathbun, 1896 (Baldwin and Johnsen, 2012). Watanabe et al. (2015) suggests that the color variation related to the size of $C$. hellerii may indicate a dominance hierarchy among individuals for resources such as food and females available for mating (males only).

Dilocarcinus pagei turns progressively red with increasing size, indicating an association with the onset of sexual maturity and this can be used as a character to identify an adult or those close to adulthood. The red color in larger D. pagei individuals may have the function of facilitating the choice of partners by visual stimulation during the mating period, as well as promoting greater social interaction. This red color has as a disadvantage though, in the perceived increased risk of predation when such brightly colored crabs become easier to identify in vegetation and on substrate by predators. Other brachyurans also change their colors under predation risk through the modification of growth rates caused by stress (Henmi et al., 2006). Silbiger and Munguia (2008) reported that seasonal temperature changes can affect growth and promote color variation in mangrove crabs. However, further studies are needed to better understand how environmental parameters may influence Dilocarcinus pagei color variation.

\section{ACKNOWLedgment}

Thanks go to the members of the Research Group on Biology and Production of Amazonic Aquatic Organisms (ICET/UFAM). Financial support was provided by Fundação de Amparo a Pesquisa do Estado do Amazonas (FAPEAM) for the PAPAC Program (G.Y.H. \#062.02602/2014), Universal Amazonas Program (G.Y.H\#062.01258/2018) fellowships PAIC and POSGRAD (N,A.P), the Conselho Nacional de Desenvolvimento Científico Tecnológico (CNPq) (G.Y.H.\#478456/2007-7; \#483058/2010-6) and the Coordenação Aperfeiçoamento de Pessoal de Nível Superior (CAPES/PROAP).

\section{RefERÊNCIAS}

Affonso, I.P. and Signorelli, L. 2011. Predation on frogs by the introduced crab Dilocarcinus pagei Stimpson, 1861 (Decapoda, Trichodactylidae) on a neotropical floodplain. Crustaceana, 84: 1653-1657.

Baldwin, J. and Johnsen, S. 2012. The male blue crab, Callinectes sapidus, uses both chromatic and achromatic cues during mate choice. Journal of Experimental Biology, 215: 1184-1191.

Casariego, A.M.; Luppi, T. and Iribarne, O. 2011. Differential coloration patterns in the intertidal crab Neohelice granulate. Journal of the Marine Biological Association of the United Kingdom, 91: 1041-1047.

Cummings, M.E.; Jordao, J.M.; Cronin, T.W. and Oliveira, R.F. 2008. Visual ecology of the fiddler crab, Uca tangeri: effects of sex, viewer and background on conspicuousness. Animal Behaviour, 75: 175-188.

Daniels, S.R. 2001. Allometric growth, handedness, and morphological variation in Potamonautes warren (Calman, 1918) (Decapoda, Brachyura, Potamonautidae) with a redescription of the species. Crustaceana, 74: 237-253.

Davanso, T.M.; Taddei, F.G.; Simões, S.M.; Fransozo, A. and Costa, R.C. 2013. Population dynamics of the freshwater crab Dilocarcinus pagei in tropical waters in southeastern Brazil. Journal of Crustacean Biology, 33: 235-243.

Davanso, T.M.; Taddei, F.G.; Hirose, G.L. and Da Costa, R.C. 2016. Sexual maturity, handedness and sexual dimorphism of the freshwater crab Dilocarcinus pagei in Southeastern Brazil. Boletim do Instituto de Pesca, 42: 269-279.

Detto, T.; Zeil, J.; Magrath, R.D. and Hunt, S. 2004. Sex, size and colour in a semi-terrestrial crab, Heloecius cordiformis (H. Milne Edwards, 1837). Journal of Experimental Marine Biology and Ecology, 302: 1-15. 
Detto, T.; Backwell, P.; Hemmi, J.M. and Zeil, J. 2006. Visually mediated species and neighbour recognition in fiddler crabs (Uca mjoebergi and Uca capricornis). Proceedings of the Royal Society of London B: Biological Sciences, 273: 1661-1666.

Detto, T. 2007. The fiddler crab Uca mjoebergi uses colour vision in mate choice. Proceedings of the Royal Society of London B: Biological Sciences, 274: 2785-2790.

Ghidalia, W. 1985. Structural and biological aspects of pigments. p. 301-394. In: D.E. Bliss and L.H. Mantel (eds), Integument, Pigments, and Hormonal Processes. The Biology of Crustacea, vol. 9. Orlando, Academic Press.

Hemmi, J.; Marshal, J.; Pix, W.; Vorobyev, M. and Zeil, J. 2006. The variable colours of the fiddler crab Uca vomeris and their relation to background and predation. Journal of Experimental Biology, 209: 4140-4153.

Herrera, D.R.; Davanso, T.M.; Costa, R.C. and Taddei, F.G. 2013. The relative growth and sexual maturity of the freshwater crab Dilocarcinus pagei (Brachyura, Trichodactylidae) in the northwestern region of the state of São Paulo. Iheringia. Série Zoologia, 103: 232-239.

Lee, K.T. and Vespoli, J.L. 2015. Tracking Color Change in Individual Green Crabs, Carcinus maenas (L.). Northeastern Naturalist, 22: 413-423.

Magalhães, C. 2003. Famílias Pseudothelphusidae e Trichodactylidae. p. 143-287. In: G.A.S. Melo (ed), Manual de Identificação dos Crustacea Decapoda de Água Doce do Brasil. São Paulo, Editora Loyola.

Magalhães, C. 2016. Avaliação dos caranguejos tricodactilídeos (Decapoda: Trichodactylidae). p. 420-440. In: M.A.A. Pinheiro and H. Boos, (Org), Livro Vermelho dos Crustáceos do Brasil: Avaliação 2010-2014. Porto Alegre, RS, Sociedade Brasileira de Carcinologia - SBC.

Magalhães, C.; Campos, M.R.; Collins, P.A. and Mantelatto, F.L. 2016. Diversity, distribution and conservation of freshwater crabs and shrimps in South America. In: T. Kawai and N. Cumberlidge (eds), A Global Overview of the Conservation of Freshwater Decapod Crustaceans. Cham, Switzerland, Springer International Publishing AG.

Maoka, T. 2011. Carotenoids in marine animals. Marine drugs, 9: 278-293.

Matsuno, T.2001. Aquatic animal carotenoids. Fisheries science, 67: 771-783.

Nasir, U. and Faulkes, Z. 2011. Color polymorphism of sand crabs, Lepidopa benedicti (Decapoda: Anomura: Albuneidae). Journal of Crustacean Biology, 31: 240-245.

Pinheiro, M.A.A. and Taddei, F.G. 2000. Chromatic alteration in Arenaeus cribrarius (Lamarck) (Crustacea, Portunidae): an indicator of sexual maturity. Revista Brasileira de Zoologia, 17: $945-951$.
Rao, K.R. 2001. Crustacean Pigmentary-Effector Hormones: Chemistry and Functions of RPCH, PDH, and Related Peptides. American Zoologist, 41: 364-379.

Sant'anna, B.S.; Andrade, D.R.; Watanabe, T.T. and Hattori, G. Y. 2014. Behavioral repertoire and substrate choice of the freshwater crab Dilocarcinus pagei Stimpson, 1861 (Decapoda, Trichodactylidae). p. 57-73. In: C. Ardovini (ed), Crabs: Global Diversity, Behavior and Environmental Threats. New York: Nova Science Publishers.

Sant'anna, B.S.; Takahashi, E.L.H. and Hattori, G.Y. 2015. Experimental culture of the freshwater crab Dilocarcinus pagei: effect of density on the growth. Boletim do Instituto de Pesca, 41: 645-653.

Senkman, L.E.; Negro, C.L.; Lopretto, E.C. and Collins, P.A. 2015. Reproductive behaviour of three species of freshwater crabs of the family Trichodactylidae (Crustacea: Decapoda) including forced copulation by males. Marine and Freshwater Behaviour and Physiology, 48: 77-88.

Shahidi, F. and Synowiecki, J. 1991. Isolation and characterization of nutrients and value-added products from snow crab (Chionoecetes opilio) and shrimp (Pandalus borealis) processing discards. Journal of Agricultural and Food Chemistry, 39: 15271532.

Silbiger, N. and Munguia, P. 2008. Carapace color change in $U_{c a}$ pugilator as a response to temperature. Journal of Experimental Marine Biology and Ecology, 355: 41-46.

Silva, C.C.; Schwamborn, R. and Oliveira, J.E. 2014. Population biology and color patterns of the blue land crab, Cardisoma guanhumi (Latreille 1828) (Crustacea: Gecarcinidae) in the Northeastern Brazil. Brazilian Journal of the Biology, 74: 949-958.

Taddei, F.G. and Herrera, D.R. 2010. Crescimento do caranguejo Dilocarcinus pagei Stimpson, 1861 (Crustacea, Brachyura, Trichodactylidae) na represa Barra Mansa, Mendonça, SP. Boletim do Instituo de Pesca, 36: 99-100.

Takeda, S. 2006. Behavioural evidence for body colour signaling in the fiddler crab Uca perplexa (Brachyura: Ocypodidae). Journal of Experimental Marine Biology and Ecology, 330: 521-527.

Thurman, C.L. 1988. Rhythmic physiological color change in crustacea: a review. Comparative Biochemistry and Physiology Part C: Comparative Pharmacology, 91: 171-185.

Watanabe, T.T.; Zara, F.J.; Hattori, G.Y.; Turra, A. and Sant'Anna, B.S. 2015. Biological associations of color variation in the Indo-Pacific swimming crab Charybdis hellerii. Anais da Academia Brasileira de Ciências, 87: 219-232.

Yeo, D.C.; Ng, P.K.; Cumberlidge, N.; Magalhães, C.; Daniels, S.R.; and Campos, M.R. 2008. Global diversity of crabs (Crustacea: Decapoda: Brachyura) in freshwater. Hydrobiologia, 595: 275-286. 